\title{
Does outcome feedback make you a better emergency physician? A systematic review and research framework proposal
}

\author{
Curtis F. Lavoie, MD; ${ }^{*}$ Howard Schachter, $\mathrm{PhD} ;{ }^{\dagger}$ AvivaT. Stewart, MD; ${ }^{\ddagger}$ Jessie McGowan, MLIS, AHIP§
}

See related articles on pages 523 and 566

\section{ABSTRACT}

Objective: The organization of emergency medical care limits the ability of emergency physicians to know the outcomes of most of their patients after the patients leave the emergency department. This lack of outcome feedback may hinder the practice of emergency medicine (EM) by preventing "calibration" of the decision tools of practitioners. We sought to determine what is currently known about outcome feedback in EM, including its incidence, impact and modifiers.

Data source: We searched the following databases: PreMEDLINE, MEDLINE, EMBASE, CINAHL, CENTRAL, PsycINFO, DARE, Health Technology Assessment Database and AMED. We performed manual searches on abstract databases, reference lists, various health information and research websites, and nonindexed journals.

Study selection: Selection entailed a 2-step screening process to exclude articles not pertaining to outcome feedback in EM.

Data extraction: Our search yielded 1128 bibliographic records, from which screening identified 7 relevant reports: 5 surveys, 1 system level evaluation and 1 intervention trial.

Data synthesis: All studies were found to have "inadequate" or "unable to assess" reporting and study quality. Systems for outcome feedback to EM residents have been increasingly available since 1984, though they are perceived to be inadequate. Commonly used mechanisms for outcome feedback include automatic routing of discharge summaries, case conferences for admitted patients and telephone calls to patients or families for discharged patients. With respect to attending emergency physicians, no conclusions or clinical recommendations can be made given the level of available evidence.

Conclusion: The potential importance of outcome feedback remains, at this time, underevaluated. We propose a research framework, and hypothesize that increasing outcome feedback would increase emergency physician diagnostic accuracy, therapeutic outcomes, clinical efficiency and job satisfaction. Future research in this area should include surveys and focus groups, as well as simulated or real-world intervention trials.

Keywords: treatment outcome, quality of health care, emergency medicine, decision support techniques, outcome feedback

\section{RÉSUMÉ}

Objectif : L'organisation des soins médicaux d'urgence limite la capacité des médecins d'urgence de connaître le devenir de la plupart de leurs patients après leur passage à l'urgence. Le manque d'information sur les résultats peut nuire à la pratique de la médecine d'urgence en empêchant "l'étalonnage " des outils de prise de décisions qu'utilisent les praticiens. Nous avons cherché à déterminer ce que l'on sait actuellement de l'information sur les résultats en médecine d'urgence, y compris son incidence, son impact et ses modificateurs.

Source des données: Nous avons interrogé les bases de données suivantes: PreMEDLINE, MEDLINE, EMBASE, CINAHL, CENTRALE, PsycINFO, DARE, Health Technology Assessment Database et AMED. Nous avons aussi réalisé des recherches manuelles de bases de données de résumés, de listes de référence, de divers sites Web d'information sur la santé et de sites de recherche et de revues non indexées.

Sélection pour l'étude : La sélection s'est déroulée en deux étapes visant à exclure les articles ne traitant pas d'information sur les résultats en médecine d'urgence.

Extraction des données : Notre recherche a produit 1128 dossiers bibliographiques, pour lesquels une sélection à permis de retenir 7 rapports pertinents : 5 enquêtes, 1 étude d'évaluation

From the *Emergency Department, Hôpital Montfort, and the Division of Emergency Medicine, Children's Hospital of Eastern Ontario, Ottawa, Ont., the TProvincial Centre of Excellence for Child and Youth Mental Health, Children's Hospital of Eastern Ontario Research Institute II, Ottawa, Ont., the ‡Division of Emergency Medicine, Children's Hospital of Eastern Ontario Research Institute, Ottawa, Ont., and the §Institute for Population Health, University of Ottawa, Ottawa, Ont.

Submitted Jul. 25, 2008; Revised Mar. 23, 2009; Accepted Mar. 25, 2009

This article has been peer reviewed. 
du système et 1 essai interventionnel.

Synthèse des données : Nous avons conclu que la clarté et la qualité de toutes les études étaient " inadéquates " ou " ne pouvaient être évaluées ". Depuis 1984, des systèmes d'information sur les résultats à l'intention des résidents en médecine d'urgence sont de plus en plus disponibles, même s'ils sont perçus comme étant inadéquats. Des mécanismes d'obtention d'information sur les résultats couramment utilisés comprennent le routage automatique des résumés de congé, les conférences de cas pour les patients hospitalisés et les appels téléphoniques aux patients ayant obtenu leur congé ou à leurs familles. En ce qui concerne les médecins d'urgence traitants, on ne peut formuler aucune conclusion ou recommandation clinique, compte tenu du niveau de preuves disponibles.

Conclusion : L'importance éventuelle de l'information sur les résultats concernant le devenir des patients demeure, à ce moment, sous-évaluée. Nous proposons un cadre de recherche et avançons I'hypothèse qu'une plus grande communication de telles informations accroîtrait la précision du diagnostic des médecins d'urgence, les résultats thérapeutiques, l'efficacité clinique et la satisfaction professionnelle. La recherche future dans ce domaine devrait comprendre des enquêtes et des groupes de discussion, ainsi que les essais interventionnels simulés ou réels.

\section{INTRODUCTION}

Emergency medicine (EM) is a 24-7, on-demand, highpressure discipline that provides care for a wide spectrum of illness and the sickest of patients, yet it includes very little opportunities for follow-up to learn the outcomes of these patients. Put another way, emergency physicians almost never see their patients again and rarely hear what happens to them. However, this is not the case for other medical specialties. From primary care medicine to tertiary care surgical services, most physicians have the benefit of scheduled follow-up visits, if not extended observation, after diagnostic or therapeutic interventions. It is through this follow-up that these practitioners receive outcome information that confirms or challenges their initial decisions and their decision-making processes. ${ }^{1}$ Moreover, it is in this way that physicians learn from their patients and gain clinical experience. The consequences of the lack of outcome feedback for emergency physicians concern us, and as a result we sought to systematically review the available evidence concerning this phenomenon.

Concerns about a lack of outcome feedback in EM are not new. Croskerry ${ }^{1}$ suggested that emergency physicians have great difficulty finding out what happens to their patients and that most "lament" this loss of information. However, he noted that with time emergency physicians come to accept this as part of the development of what he calls an "adaptive myopia." Croskerry states that the problem is that such information is crucial to calibrating the diagnostic tools of physicians and without it they tend to become overconfident in their diagnostic strategies. ${ }^{1}$

There are many types of feedback in the practice of medicine, and as such, the concept of outcome feedback in EM requires clarification. Outcome feedback, as we define it, is limited to the natural process of finding out what happens to one's patients after their evaluation and treatment in the emergency department (ED). Did they improve, or did they deteriorate? Did another doctor make a new diagnosis at a later time? Did anything unexpected happen? We specifically exclude the outcome of tests that were performed during the ED visit in our definition (e.g., bacterial cultures that are reported later or radiographs done at the time of consultation that are later interpreted by a radiologist) since these do not reflect evolution or rediagnosis of a patient's condition. We also exclude evaluative types of feedback in our definition, whereby individuals might critique the care provided to patients. This might occur during educational activities and training (by mentors or supervisors), during audits by peers or other professionals, or by surveying patients and families themselves after the visit. Although these types of feedback all have value, they are quite different from the natural phenomenon of simply finding out what happens to our patients after they leave our care.

We undertook this review to determine what is currently known about outcome feedback in EM. This includes but is not limited to the incidence, the impact and the modifiers of outcome feedback in EM. In other words, how much outcome feedback do emergency physicians receive now, what effect does it have on practice, and what factors make it more or less useful?

\section{METHODS}

\section{Study design}

We developed a comprehensive search strategy and applied it to Ovid's MEDLINE database for articles from 1950 until November 2008 (Box 1). We developed the search strategy using medical subject headings and text words for the general concepts of 1) emergency 
medicine, 2) patient/treatment outcomes and discharge and 3) feedback and decision support techniques. This was subsequently adapted for and applied to the following databases: PreMEDLINE, EMBASE, CINAHL (Cumulative Index to Nursing and Allied Health Literature), CENTRAL (Cochrane Central Register of Controlled Trials), PsycINFO, DARE (Database of Abstracts of Reviews of Effects), Health Technology Assessment Database, and AMED (Allied and Complementary Medicine Database). There were no restrictions placed on the EM context, trainee versus attending physician status, language of publication, publication status (e.g., unpublished evidence) or experimental design for intervention studies.

Other sources reviewed were reference lists of relevant reports and selected review articles; the literature files of 3 experts (Dr. Chii-Hwa Chern, Veterans General Hospital, Taipei and National Yang-Ming University, Taipei, Taiwan: personal communication, 2006; Dr. Pat Croskerry, Department of Emergency Medicine, Dartmouth General Hospital, Dartmouth, NS: personal communication, 2006; Dr. Louis Graff, New Britain General Hospital, New Britain, Conn.: personal communication, 2006); the websites of key health information and research foundations; $;^{2-10}$ and 4 key

\footnotetext{
Box 1. Outcome feedback in emergency medicine Ovid search strategy

1. Emergency Medicine/

2. exp Emergency Service, Hospital/

3. emergenc\$.tw.

4. 2 or 3

5. Physicians/

6. (physician $\$$ or doctor $\$$ or specialist $\$$ ).tw.

7. "Internship and Residency"/

8. or/5-7

9. 4 and 8

10. 1 or 9

11. exp treatment outcome/

12. quality of health care/

13. patient outcome\$.tw.

14. diagnostic accuracy.tw.

15. diagnostic errors/

16. patient discharge/

17. Follow-Up Studies/

18. or/11-17

19. 10 and 18

20. exp decision support techniques/

21. feedback.tw,sh.

22. 20 or 21

23. 19 and 22
}

international EM websites. ${ }^{11-14}$ In addition, we manually searched the 1998-2008 issues of the Canadian Journal of Emergency Medicine (CJEM), and the abstracts published by the Society for Academic Emergency Medicine $^{15}$ (2003-2008) and the Canadian Association of Emergency Physicians (CJEM 2003-2008). We entered search results into Endnote citation management software, version 5.0 (Thompson Reuters), and removed duplicates.

\section{Selection process}

Eligibility criteria for this review included any research addressing outcome feedback (defined as "physicians knowing the outcomes of their patients after discharge from their care") provided to emergency physicians or trainees, excluding any feedback on the "results of diagnostic tests performed during care" or feedback involving "a critique" (i.e., a comparison of the outcome or management of a case to a standard of care or an expert opinion). Two reviewers (C.L. and A.S.) underwent a calibration exercise that employed 10 preselected bibliographic records to ensure conformity to the review objectives. Reviewers then performed a dual independent review of the search results. The first level of screening, using only the bibliographic records including abstracts, excluded only those records for which there was clear and unequivocal agreement as to their irrelevance. We retrieved the corresponding full-text reports for the remainder of the records and performed a second screening using the same eligibility criteria. We resolved disagreements via forced consensus. We calculated interrater agreement at both levels of screening. Reports were included in this review if they passed both levels of screening and reported original research.

\section{Quality and relevance assessment}

We informally assessed all relevant studies for quality of reporting, study design and relevance. For reporting quality we assigned labels of "adequate," "inadequate" or "unable to assess," based on the clarity of the methods and results in the paper and their ability to permit replication of the study. The same labels were assigned in evaluating the study design of survey and intervention reports. For surveys, this determination was based on the ability of the methodology to elicit true frequency data. To do this we considered sampling bias, response rate and whether "outcome feedback" was well defined in the survey. In evaluating the study design of 
intervention reports we assessed relevance by looking for specific biases including "nonoutcome contamination bias." Since outcome feedback refers only to information on what actually happens to the patients, feedback of evaluative information such as found in audits, advice or similar information, would constitute a contamination of the intervention. The heterogeneity of the reports, the novelty of the topic and the uniformly low quality prevented a more formal assessment using standardized evaluation tools.

\section{RESULTS}

The database search yielded 1128 unique references that underwent primary screening. This process identified 45 potentially relevant reports, and we found an additional 9 reports through review of reference lists and a manual search of journals. Of the 54 potentially relevant reports, we obtained the original articles for 53 and, from these, we deemed 7 relevant for review. The interobserver agreement $(\kappa)$ was 0.97 during the

\section{Table 1. Studies that address the occurrence and perceptions of outcome feedback in emergency medicine}

\begin{tabular}{|c|c|c|c|c|c|c|c|c|c|c|}
\hline \multirow[b]{2}{*}{ Study } & \multirow[b]{2}{*}{$\begin{array}{c}\text { Survey } \\
\text { respondents }\end{array}$} & \multirow[b]{2}{*}{$\begin{array}{l}\text { Focus } \\
\text { population }\end{array}$} & \multirow[b]{2}{*}{$\begin{array}{l}\text { Year of } \\
\text { survey }\end{array}$} & \multicolumn{2}{|c|}{$\begin{array}{c}\text { System } \\
\text { availability, } \%\end{array}$} & \multicolumn{2}{|c|}{ Mechanism availability, $† \%$} & \multirow[b]{2}{*}{$\begin{array}{c}\text { Desire } \\
\text { improvement, } \neq \\
\%\end{array}$} & \multirow[b]{2}{*}{$\begin{array}{l}\text { Reporting } \\
\text { quality§ }\end{array}$} & \multirow[b]{2}{*}{$\begin{array}{l}\text { Study } \\
\text { quality }\end{array}$} \\
\hline & & & & $\begin{array}{c}\text { ADM } \\
\text { pt }\end{array}$ & $\begin{array}{c}\text { DISCH } \\
\text { pt }\end{array}$ & ADM pt & DISCH pt & & & \\
\hline \multirow{2}{*}{$\begin{array}{l}\text { Osborn } \\
\text { and } \\
\text { Negron }^{17}\end{array}$} & $\begin{array}{l}\text { EM residency } \\
\text { program }\end{array}$ & EM residents & 1984 & $38^{* *}$ & $\mathrm{NR}$ & NR & NR & 71 & \multirow{2}{*}{$\begin{array}{l}\text { Unable to } \\
\text { assess } \\
\text { (abstract only) }\end{array}$} & \multirow[t]{2}{*}{$\begin{array}{l}\text { Unable to } \\
\text { assess }\end{array}$} \\
\hline & directors & & 1988 & 55 & $33^{* *}$ & & & & & \\
\hline \multirow{4}{*}{$\begin{array}{l}\text { Gaeta } \\
\text { and } \\
\text { Osborn }^{20}\end{array}$} & $\begin{array}{l}\text { EM residency } \\
\text { program }\end{array}$ & EM residents & 1992 & 69 & 36 & $\begin{array}{c}\text { Disch.sum.: } \\
55\end{array}$ & $\begin{array}{l}\text { Telephone } \\
\text { calls: } 86\end{array}$ & NR & \multirow{4}{*}{$\begin{array}{l}\text { Inadequate } \\
\text { (lacks details } \\
\text { of survey } \\
\text { development) }\end{array}$} & \multirow[t]{4}{*}{$\begin{array}{l}\text { Unable to } \\
\text { assess }\end{array}$} \\
\hline & & & 1996 & 74 & 51 & $\begin{array}{c}\text { Case } \\
\text { conferences: } \\
56\end{array}$ & $\begin{array}{l}\text { Follow-up } \\
\text { logs: } 24\end{array}$ & & & \\
\hline & & & & & & $\begin{array}{l}\text { Follow-up } \\
\text { logs: } 47\end{array}$ & $\begin{array}{l}\text { Follow-up } \\
\text { clinic: } 24\end{array}$ & & & \\
\hline & & & & & & & $\begin{array}{c}\text { Home } \\
\text { visits: < } 1\end{array}$ & & & \\
\hline $\begin{array}{l}\text { Adams } \\
\text { and } \\
\text { Keller }^{16}\end{array}$ & $\begin{array}{l}\text { Chief } \\
\text { residents in } \\
\text { EM }\end{array}$ & EM residents & NR & NR & NR & $\begin{array}{c}\text { Disch.sum.: } \\
21\end{array}$ & NR & 67 & $\begin{array}{l}\text { Unable to } \\
\text { assess } \\
\text { (abstract only) }\end{array}$ & $\begin{array}{l}\text { Unable to } \\
\text { assess }\end{array}$ \\
\hline $\begin{array}{l}\text { Bentley } \\
\text { et al. } .^{19}\end{array}$ & $\begin{array}{l}\text { EM residency } \\
\text { program } \\
\text { directors }\end{array}$ & EM residents & NR & 34 & 66 & $\begin{array}{c}\text { Disch.sum.: } \\
53\end{array}$ & NR & 77 & $\begin{array}{l}\text { Inadequate } \\
\text { (lacks details } \\
\text { of survey } \\
\text { development) }\end{array}$ & $\begin{array}{l}\text { Unable to } \\
\text { assess }\end{array}$ \\
\hline \multirow[t]{4}{*}{ Wogan $^{18}$} & \multirow[t]{4}{*}{ ED chiefs } & \multirow[t]{4}{*}{$\begin{array}{l}\text { Emergency } \\
\text { physicians }\end{array}$} & \multirow[t]{4}{*}{ NR } & \multirow[t]{4}{*}{ NR } & \multirow[t]{4}{*}{ NR } & $\begin{array}{l}\text { Disch.sum.: } \\
\quad 25 \\
\text { Informal: } 56\end{array}$ & NR & NR & \multirow{4}{*}{$\begin{array}{l}\text { Unable to } \\
\text { assess (letter } \\
\text { to the editor } \\
\text { only) }\end{array}$} & \multirow[t]{4}{*}{$\begin{array}{l}\text { Inadequate } \\
\text { (response } \\
\text { rate } 48 \% \text { ) }\end{array}$} \\
\hline & & & & & & $\begin{array}{l}\text { ED Q\&A†† } \\
\text { activity: } 46\end{array}$ & & & & \\
\hline & & & & & & $\begin{array}{l}\text { Hospital } \\
\text { Q\&At†: } 33\end{array}$ & & & & \\
\hline & & & & & & $\begin{array}{l}\text { M\&M†† } \\
\text { rounds: } 18\end{array}$ & & & & \\
\hline $\begin{array}{l}\text { ADM = ad } \\
\text { NR = not I } \\
\text { *Proportio } \\
\text { †Types of } \\
\text { †Percenta } \\
\text { §Clarity of } \\
\text { १Clarity of } \\
\text { ** Re-repo } \\
\text { †+The exp }\end{array}$ & $\begin{array}{l}\text { dmitted; DISCH = } \\
\text { reported; } \mathrm{pt}=\text { pati } \\
\text { on of centres havin } \\
\text { outcome feedbac } \\
\text { ge of respondents } \\
\text { reporting that wo } \\
\text { orted by in eliciting } \\
\text { orted byeta and } \\
\text { onded forms of } N\end{array}$ & $\begin{array}{l}\text { discharged; Disch } \\
\text { ient(s). } \\
\text { ng system for out } \\
\text { ck mechanisms an } \\
\text { s feeling the curre } \\
\text { ould permit the re } \\
\text { g accurate frequer } \\
\text { d Osborn. }{ }^{20} \\
\text { M\&M and Q\&A we }\end{array}$ & $\begin{array}{l}\text { h.sum. = } \\
\text { tcome feed } \\
\text { nd the pro } \\
\text { ent outcon } \\
\text { eplication o } \\
\text { ncies. } \\
\text { ere not de }\end{array}$ & $\begin{array}{l}\text { discharge } \\
\text { dback, by } \\
\text { portion of } \\
\text { ne feedba } \\
\text { f the stud } \\
\text { fined in th }\end{array}$ & $\begin{array}{l}\text { mmaries } \\
\text { ar and ty } \\
\text { ntres usi } \\
\text { system i } \\
\text { article. }\end{array}$ & $\begin{array}{l}\text { odmitted patient } \\
\text { e of patient. } \\
\text { g them. } \\
\text { inadequate or sho }\end{array}$ & $\begin{array}{l}\text { s; ED =emerge } \\
\text { ould be improve }\end{array}$ & $\begin{array}{l}\text { gency departme } \\
\text { ed. }\end{array}$ & $M=$ emergen & medicine; \\
\hline
\end{tabular}


primary screening and 0.81 during the secondary screening. Five reports described efforts concerning the prevalence of outcome feedback in EM or the perceived need for more outcome feedback (Table $1^{16-20}$ ) and 2 reports addressed the impact of outcome feedback interventions (Table 21,22). Quality assessments were generally hampered by the method of reporting: 2 were only available as abstracts ${ }^{16,17}$ and 1 only as a letter to the editor. ${ }^{18}$ We were unable to contact authors to obtain more information. As a result we are only able to present a qualitative and descriptive appraisal of the results.

\section{Outcome feedback: mechanisms, prevalence and perceptions}

Table 1 summarizes 5 reports of physician surveys concerning the availability and perceptions of outcome feedback systems. None of the studies reported the actual percentage of patients for whom outcome feedback was available.

The first 4 reports were surveys of EM residents and program directors, and largely investigated compliance with a requirement for outcome feedback by the Residency Review Committee in Emergency Medicine in the United States. This requirement has been in place since $1980,{ }^{22}$ and states that EM residency programs must "assure that the residents follow-up on a represen- tative sample of patients so as to learn about the results of diagnostic studies, the outcome of interventions, and the final patient diagnosis." ${ }_{23}$ The fifth study examined the habits of attending physicians.

Three of these studies ${ }^{17,19,20}$ surveyed EM residency program directors, over several years. The results indicate that outcome feedback systems for EM residents have been increasingly available since 1984 .

Four of these studies looked at the availability of specific outcome feedback mechanisms, including one which surveyed attending emergency physicians. For admitted patients, automatic mailing of discharge summaries and case conferences (or quality assurance activities) were reported to be the most commonly available mechanisms for EM residents, ${ }^{16,19,20}$ as well as the most popular for attending emergency physicians. ${ }^{18}$ Only 1 study looked at mechanisms of outcome feedback for discharged patients. This reported that the use of direct telephone calls to patients was the outcome feedback mechanism most commonly available for EM residents. ${ }^{20}$ Three studies surveyed EM residents or residency program directors about their perceptions of these systems of outcome feedback and all found a $60 \%$ or higher rate of dissatisfaction or desire for improvement. ${ }^{16,17,19}$ The reporting and study quality of all reports were deemed to be "inadequate" or "unable to assess."

\begin{tabular}{|c|c|c|c|c|c|c|}
\hline Study & Study design & $\begin{array}{c}\text { Target } \\
\text { physicians* }\end{array}$ & $\begin{array}{l}\text { Outcome info } \\
\text { retrievalt }\end{array}$ & $\begin{array}{l}\text { Outcome info } \\
\text { delivery } \ddagger\end{array}$ & Study outcome & Study quality/relevance§ \\
\hline Chern et al. ${ }^{21}$ & $\begin{array}{l}\text { Controlled } \\
\text { intervention } \\
\text { study } \\
\text { (before \& } \\
\text { after) }\end{array}$ & $\begin{array}{l}\text { Residents } \\
\text { EM rotation }\end{array}$ & $\begin{array}{l}\text { Staff MD phone } \\
\text { call to high-risk } \emptyset \\
\text { discharged } \\
\text { patients }\end{array}$ & $\begin{array}{l}\text { Verbal } \\
\text { feedback to } \\
\text { resident at } \\
<48 \mathrm{~h}\end{array}$ & $\begin{array}{l}\text { - Adverse event** rate } \\
\text { in high-risk patients: } \\
\text { - Control: } 4.1 \% \\
\text { - Intervention: } 1.5 \% \\
\text { (drop of } 2.6 \%, 95 \% \mathrm{Cl} \\
0.3 \%-4.8 \% \text { ) }\end{array}$ & $\begin{array}{l}\text { - Adequate reporting } \\
\text { - Inadequate design } \\
\text { (lack of outcome } \\
\text { validation, lack of } \\
\text { blinding, seasonal } \\
\text { confounders) } \\
\text { - Moderate relevance } \\
\text { (nonoutcome } \\
\text { contamination) }\end{array}$ \\
\hline Sadosty et al. ${ }^{22}$ & $\begin{array}{l}\text { System } \\
\text { evaluation } \\
\text { study }\end{array}$ & $\begin{array}{l}\text { Residents } \\
\text { EM program }\end{array}$ & $\begin{array}{l}\text { Various, by } \\
\text { resident }\end{array}$ & NA & $\begin{array}{l}\text { Educational for the } \\
\text { resident? (yes) } \\
\text { Residents: } 81.3 \% \\
\text { Faculty: } 80.4 \%\end{array}$ & $\begin{array}{l}\text { - Adequate reporting } \\
\text { - Inadequate design } \\
\text { ("educational" not } \\
\text { defined, no control } \\
\text { group) } \\
\text { - High relevance }\end{array}$ \\
\hline \multicolumn{7}{|c|}{$\begin{array}{l}\text { Cl=confidence interval; } \mathrm{EM}=\text { emergency medicine; } \mathrm{MD}=\text { medical doctor; } \mathrm{NA}=\text { not applicable. } \\
\text { *Physicians receiving the outcome feedback. } \\
\text { †Means of information retrieval, and person obtaining outcome information. } \\
\text { fMeans by which outcome feedback is delivered. } \\
\text { §Explicit attempts to minimize the role of confounding influences. } \\
\text { П Charts were reviewed and flagged "high risk" according to defined criteria. } \\
\text { ** Chern et al. use the term "clinically significant adverse event," defined as a return visit with "serious management error (misdiagnosis or erroneous } \\
\text { treatment plan) resulting in death or prolonged admission (admission for }>3 \text { days)." }\end{array}$} \\
\hline
\end{tabular}




\section{The impact of outcome feedback}

Table 2 summarizes the articles that address the impact of outcome feedback in EM. The first study by Chern and colleagues ${ }^{21}$ was a controlled intervention study that found a significant reduction in adverse events in response to telephone outcome feedback. This was a before-and-after study of the effect of outcome feedback obtained by telephone calls to patients on the rate of adverse patient outcomes in a Taiwanese hospital. In the 15-week control period (Apr. 15-Jul. 31, 2001), 2 senior emergency physicians reviewed all emergency charts every second day and telephoned all discharged patients flagged as "high-risk" within 24 hours of discharge. The criteria for high-risk flagging included a total of 40 neurologic, cardiovascular, pulmonary, gastrointestinal and infectious conditions, as well as any patients who were intoxicated or had abnormal laboratory values. During the 15 -week intervention period (Aug. 1-Nov. 15), this process continued and the outcome information obtained was given back (within 2 days) to the resident involved in the initial patient care. Using a review of admissions and repeated telephone calls to patients who did not improve, the authors monitored the rate of clinically significant adverse events (CSAEs), which were defined as return visits with serious management error (misdiagnosis or erroneous treatment plan) resulting in death, or admission for longer than 3 days." ${ }^{21}$

During this outcome feedback intervention, Chern and coworkers ${ }^{21}$ observed a drop in the rate of CSAEs in high-risk cases from $4.1 \%$ in the control period to $1.5 \%$ during the intervention period (a reduction of $2.6 \%, 95 \%$ confidence interval $0.3 \%-4.8 \%$ ), and relative reduction of the overall CSAE rate of more than $50 \%$, from $0.9 \%$ to $0.4 \%$ (reduction of $0.5 \%, 95 \%$ confidence interval $0.1 \%-0.9 \%) .{ }^{21}$ However, a number of limitations of this study merit consideration. First, the outcome information provided to the residents was combined with other feedback including a discussion of "the pitfalls in diagnosis or management, [and] appropriate performance that might avoid adverse event recurrence and the possible error." This nonoutcome information may have affected physician performance and therefore patient outcomes. Second, the control and intervention periods had potentially significant differences: they occurred during different seasons, did not have equivalently trained residents and did not have equivalent teaching rounds. Furthermore, "shift change-over rounds" (i.e., lectures that "focused on the need to understand the uncertain nature of many ED conditions, the causes of return visits with adverse events, and the utility of using resources available to manage uncertain ED conditions") were introduced during the intervention period. Finally, neither the high-risk criteria nor the CSAE definition were validated, and no independent or blinded review of outcomes was obtained. These various potential confounders and sources of bias are likely to have obscured the true relationship between pure outcome feedback and adverse events.

In the final study, Sadosty and colleagues ${ }^{22}$ evaluated a Web-based outcome follow-up system for EM residents. These trainees followed 1 patient per shift and documented the details on a Web-based e-form. Both the trainee and supervisor were then asked to rate the educational value of the case follow-ups. The vast majority of cases were deemed to be educational by both the resident and faculty reviewer. However, the definition and interpretation of "educational" was not provided, and no other outcomes were measured.

\section{DISCUSSION}

Finding out what happens to patients after they leave an emergency physician's care is a phenomenon we have called "outcome feedback." In this systematic review we found sparse literature of generally inadequate quality, from which only limited conclusions can be drawn. First, there is evidence to suggest that US EM residency programs have increased the availability of systems for outcome feedback to residents since 1984, but that these systems were perceived as inadequate by respondents. Second, the mechanisms of outcome feedback used most commonly by physicians include automatic routing of admission discharge summaries, case conferences and telephone calls to discharged patients.

\section{Outcome feedback: a research framework proposal}

Croskerry ${ }^{1}$ suggests that increasing outcome feedback to emergency physicians would improve calibration and overall effectiveness of their practice. From this review we can conclude that this important hypothesis has yet to be tested. As such, we propose a framework which centres on 3 broad questions to move forward with this topic of research.

First, what is the incidence and nature of outcome feedback occurrences within EM? In other words, how much outcome information is currently provided to 
practitioners, how is outcome information obtained, how is it provided and what are the barriers to its provision or reception? As a first step, understanding the current state of outcome feedback in EM is paramount. Is there indeed an overall deficit as Croskerry suggests? ${ }^{1}$ If so what are the barriers? Croskerry suggests several barriers to outcome feedback: a lack of awareness of its importance, time pressures and workloads, shift work structure (no contact with other providers), actionoutcome delays, scarcity of diagnoses, specialist followup deficiency, shift change-over, deficient reporting systems and numerous communication problems (e.g., handwriting). Other barriers may exist and all need to be investigated.

Second, what impact does outcome feedback have on diagnostic accuracy, treatment outcomes, clinical efficiency and job satisfaction? Based on Croskerry's suggestions, ${ }^{1}$ it is reasonable to hypothesize that diagnostic accuracy would improve through calibration. However knowing the results of treatment choices might also improve future treatment choices, resulting in better treatment outcomes. Greater clinical efficiency might result from the ability to make more rapid diagnoses, also through calibration. And job satisfaction? Consider that by not knowing the outcome of the diagnoses and treatment choices they make, emergency physicians may fail to fully understand the impact they are having on their community. We believe that job satisfaction is tied to a sense of one's role in society and hypothesize that by increasing outcome feedback, pride in one's job increases. In addition to these possible benefits, there may be negative effects to practitioners such as increased workload, overly cautious practice, emotional stress and the risks of inaccurate feedback. These would need to be determined and investigated before recommendations can be made.

Third, what are the modifiers? In other words, what are the factors that prevent or ensure any beneficial impacts while also minimizing any possible negative effects? For example, if outcome feedback is to be helpful it likely needs to be accurate and objective. It also needs to occur soon enough after the emergency visit that the physician still recalls details of the case (thus reporting delay must be avoided), yet long enough after the visit to allow for evolution in the illness or results from the treatment (thus the observation interval must be appropriate). Also the outcome information should not require excessive time, effort or expense to obtain. Furthermore the presence of subjective critiques of the physician (evaluative contamination), increased medicolegal responsibility or excessive nonoutcome information would likely diminish the utility of outcome feedback. These and other factors should be investigated.

Future research in outcome feedback will require multiple approaches. Surveys and focus groups of EM practitioners could inform on its frequency, barriers benefits and drawbacks. A controlled simulation study using either real or fictitous patient cases would inform on its impact, as well as allow manipulation of potentially modifying factors. Eventually a large real-world trial would be the most informative source of information with the greatest potential impact. Practical barriers to this may be substantial: the intervention needs to be specific to outcome information, patient confidentiality needs to be assured, and study outcomes need to be clear and objectively measured. Other studies that are limited to certain presenting complaints, diagnoses, mechanisms or patient outcomes would also be helpful in further elucidating this phenomenon.

\section{CONCLUSION}

Does finding out what happens to your patients make you a better doctor? Because of poor design and reporting quality in the available literature, there is insufficient evidence to answer this overriding question. We propose a framework for future research in outcome feedback: first, to understand the status quo (the nature, incidence and barriers); second, to investigate the impact of increased outcome feedback; and third, to assess the factors that modify this impact. Based on a model of calibration suggested by Croskerry ${ }^{1}$ we hypothesize that increased outcome feedback to emergency physicians could significantly improve the delivery of emergency medical care.

Acknowledgements: We thank Drs. Clare Liddy and Christine Harrison, and the Five Weekend Research Course funded by the Primary Health Care Transition Fund for assistance in the conception of the outcome feedback research program. The authors would also like to thank Ms. Erin Crouchman for her editorial assistance.

\section{Competing interests: None declared.}

Funding: Dr. Lavoie was supported by a salary support award from the University of Ottawa, Department of Family Medicine.

\section{REFERENCES}

1. Croskerry P. The feedback sanction. Acad Emerg Med 2000; 7:1232-8. 
2. Alberta Heritage Foundation for Medical Research [website]. Available: www.ahfmr.ab.ca/ (accessed 2009 Sep 18).

3. Health Quality Council of Alberta (formerly Alberta Health Services Utilization and Outcomes Commission) [website]. Available: www.hqca.ca (accessed 2009 Sep 18).

4. Institute for Clinical Evaluative Sciences [website]. Available: www.ices.on.ca (accessed 2009 Sep 18).

5. Canadian Agency for Drugs and Technology in Health [website]. Available: http://cadth.ca/index.php/en/home (accessed 2009 Sep 18).

6. Health Technology Assessment International [website]. Available: www.htai.org (accessed 2009 Sep 18).

7. World Health Organization Health Evidence Network [website]. Available: www.euro.who.int/HEN (accessed 2009 Sep 18).

8. Centre for Clinical Effectiveness [Monash University website]. Available: www.med.monash.edu.au/healthservices/cce/ (accessed 2009 Sep 18).

9. New York Academy of Medicine (NYAM) - Grey Literature Report. Available: www.nyam.org/library/pages/grey _literature_report (accessed 2009 Sep 18).

10. Society for Academic Emergency Medicine [website]. Available: www.saem.org/saemdnn (accessed 2009 Sep 18).

11. Australasian College of Emergency Medicine. Available: www.acem.org.au (accessed 2009 Sep 18).

12. American College of Emergency Physicians. Available: www.acep.org (accessed 2009 Sep 18).

13. Canadian Association of Emergency Physicians. Available: www.caep.ca (accessed 2009 Sep 18).

14. British Association of Emergency Medicine. Available: www.emergencymed.org.uk (accessed 2009 Sep 18).

15. Society for Academic Emergency Medicine. Available from:
www.saem.org/saemdnn/Meetings/PastAnnualMeetings/tabi d/1045/Default.aspx (accessed 2009 Oct 6).

16. Adams WH, Keller RE. Postcare follow-up in emergency medicine residencies [abstract]. Ann Emerg Med 1992;21: 617.

17. Osborn HH, Negron T. Mechanisms of emergency department patient follow-up in emergency residency programs: a national survey [abstract]. Ann Emerg Med 1990; 19:485-6.

18. Wogan JM. Emergency department follow-up of hospitalized patients. Am J Emerg Med 2000;18:510-1.

19. Bentley B, DeBehnke D, Ma O. Survey of follow-up systems in emergency medicine residencies: analysis and proposal. Acad Emerg Med 1994;1:1116-20.

20. Gaeta TJ, Osborn HH. Increasing compliance with the Residency Review Committee requirements for follow-up in academic emergency departments. Emergency Medicine Follow-up Study Group. Ann Emerg Med 1999;33:510-5.

21. Chern CH, How CK, Wang LM, et al. Decreasing clinically significant adverse events using feedback to emergency physicians of telephone follow-up outcomes. Ann Emerg Med 2005; 45:15-23.

22. Sadosty AT, Stead LG, Boie ET, et al. Evaluation of the educational utility of patient follow-up. Acad Emerg Med 2004;11:715-9.

23. Accreditation Council for Graduate Medical Education. Residency Review Committee for Emergency Medicine reviewer's checklist. Section V E. 6. Chicago (IL): The Council; 2005, Available: www.acgme.org/acWebsite/RRC_110/110_pd Checklist.pdf (accessed 2009 Sep 18).

Correspondence to: Dr. Curtis Lavoie, Emergency Department, Hôpital Montfort, 713 Montreal Rd., Ottawa ON K1K 3E9; curtislavoie@gmail.ca

\section{Change of address}

We require 6 to 8 weeks' notice to ensure uninterrupted service. Please send your current mailing label, new address and the effective date of change to:

\section{Canadian Association of Emergency Physicians}

\author{
104-1785 Alta Vista Dr. \\ Ottawa ON K1G 3 Y6 \\ 613 523-3343 \\ fax 613 523-0190 \\ admin@caep.ca
}

\section{Changement d'adresse}

Il nous faut de 6 à 8 semaines d'avis afin de vous assurer une livraison ininterrompue. Veuillez faire parvenir votre étiquette d'adresse actuelle, votre nouvelle adresse et la date de la prise d'effet du changement, à l'attention du

\section{Association canadienne des médecins d'urgence}

104-1785, prom. Alta Vista

Ottawa ON K1G 3 Y6

613 523-3343

fax 613 523-0190

admin@caep.ca 